\title{
Microbial Pigments-A Short Review
}

\author{
Dr. D. Sarvamangala ${ }^{1}$ and S.S.V.Aparna ${ }^{2}$ \\ Department of Biotechnology, GITAM Institute of Technology ${ }^{1}$, \\ Department of Biotechnology, GITAM Institute of Science ${ }^{2}$, \\ GITAM University, Visakhapatnam,-530 045, Andhra Pradesh, India
}

\begin{abstract}
Color is the main feature of any food item as it enhances the appeal and acceptability of food. In the recent years, coloring of food with pigments produced from natural sources is of worldwide interest and is gaining importance. Several types of dyes are available in the market as colouring agents to food commodities but biocolorants are now gaining popularity and considerable significance due to consumer awareness because synthetic dyes cause severe health problems. Though many natural colors are available, microbial colorants play a significant role as food coloring agents, because of their production and easy down stream processing. Industrial production of natural food colorants by microbial fermentation has several advantages such as cheaper production, easier extraction, higher yields through strain improvement, no lack of raw materials and no seasonal variations.
\end{abstract}

Keywords: Biocolorants, Synthetic dyes, Downstream process, Fermentation, Strain improvement,.

\section{Introduction}

There is worldwide interest in process development for the production of pigments from natural sources due to a serious safety problem with many artificial synthetic colourants, which have widely been used in foodstuff, cosmetic and pharmaceutical manufacturing processes ${ }^{1,2,3,4}$. It is well known that a variety of plants, animals and micro-organisms produce pigments ${ }^{5,6,7}$. Although there are a number of natural pigments, only a few are available in sufficient quantities to be useful for industry because they are usually extracted from plants $^{\mathbf{8}}$. Therefore, it is advantageous to produce natural pigments using micro-organisms.

Pigments come in a wide variety of colors, some of which are water-soluble ${ }^{9}$. Microbial pigments are of industrial interest because they are often more stable and soluble than those from plant or animal sources ${ }^{\mathbf{1 0}}$. Microorganisms can grow rapidly, which can lead to high productivity, and can produce a product throughout the year ${ }^{11}$. Most of the bacteria and fungi are widely studied for their potential as a source of food colorants. Natural pigments possess anticancer activity, contain pro-vitamin A and have some desirable properties like stability to light, heat and $\mathrm{pH}^{12}$. Thus, the food industry has become increasingly interested in the use of microbial technology to produce colors for use in foods. Special attention has been focused on the strains belonging to the Monascus genus of filamentous fungi. Some authors refer to these fungi as potent producers of natural pigments $\mathbf{s}^{\mathbf{1 3}, 14,15}$. However, there are other microorganisms which have the ability to produce pigments in high quantities, such as those belonging to the genus Paecilomyces ${ }^{\mathbf{1 6}}$, producing red, yellow, and violet pigments in quantities of up to $4.73 \mathrm{~g} / \mathrm{L}$. Microorganisms belonging to the genera Aspergillus and Penicillium have also been studied as potential producers of natural pigments ${ }^{\mathbf{1 7}, 18,19,20,21}$. The production of Monascus-like pigments from Penicillium strains has recently been reported. These pigments have a potential use in the food industry because they are not associated with citrinin production. They are homologues of pigments of Monascus which have similar chromophore polyketides ${ }^{22}$ and of fungal strains of the species Epicoccum nigrum that produce yellow pigments ${ }^{23}$. The three Penicillium sp. strains capable of producing red pigments were also isolated recently ${ }^{24}$.

Microorganisms are known to produce a variety of pigments; therefore they are promising source of food colorants ${ }^{25,26}$. Some characteristics of synthetic colorants such as detrimental effects on environment, the development of mental illness, allergies and diverse type of cancers associate with the use of artificial colorants reduced the number of synthetic colorants approved by federal regulatory agencies ${ }^{27}$. Furthermore, there is a growing demand for ecofriendly/non-toxic colorants, specifically for health sensitive applications, such as the coloration of food and dyeing of children's fabrics and leather garments ${ }^{28}$.

\section{Significance Of Microbial Pigments As Natural Colorants}

Some of the most significant natural pigments are carotenoids, flavonoids, tetrapyrroles and some xanthophylls as astaxanthin. The pigment most frequently used in industries is beta-carotene which is obtained from some microalgae and cyanobacteria. Astaxanthin produced from Phaffia rohodozoa and Haematococcus pluviais, is a red pigment of great commercial value and is used in feed, pharmaceutical and aquaculture industries. Some of the natural colorants are used in baby foods, breakfast cereals, sauces, pastas, processed 
cheese, fruit drinks, vitamin-enriched milk products, and some energy drinks. Thus, natural colors in addition to being eco-friendly, can also serve the dual need for visually appealing colors and probiotic health benefits in food products ${ }^{29}$.

\section{Microbial Pigments Of Commercial Importance}

The success of any microbial pigment produced by biotechnological means (for example fermentation) depends upon its acceptability in the market, regulatory approval, and the size of the capital investment required in bringing the product to the market. A few years ago, some expressed doubts about the positive commercialization of fermentation derived food grade pigments because of the high capital investments requirements for fermentation facilities and the expensive and time-span toxicity studies required by regulatory agencies $^{30,31}$. In addition to the above public perception of biotechnology derived products should also be taken into account for the absolute production benefit. Table. 1 states the successful microbial pigments already in use as food grade and/or nutritional supplements in the market and are derived from various bacteria, yeast and fungi. Based on the extensive research reports, these pigments broadly can be categorized into pigments of industrial production (IP), developmental stage (DS) and research project (RP) phase (Table 1) ${ }^{\mathbf{3 1}, 32}$. Microbial colorants are in use in the fish industry already, for instance, to enhance the pink color of farmed salmon. Further, some natural food colorants have commercial prospective for use as antioxidants ${ }^{\mathbf{3 3}}$. The successful marketing of pigments derived from microbes, both as a food color and a nutritional supplement, reflects the presence and significance of niche markets in which consumers are willing to pay a premium for 'all natural ingredients'.

Table 1. Pigments from various microorganisms which are already in use as natural food colorants ${ }^{31,32}$.

$\begin{array}{lllc}\text { Pigment } & \text { Color } & \text { Microorganism } & \text { Status } \\ \text { Ankaflavin } & \text { Yellow } & \text { Monascus sp. } & \text { IP } \\ \text { Anthroquinone } & \text { Red } & \text { Pencillium candidum } & \text { IP } \\ \text { Monascorubramine } & \text { Red } & \text { Monascus sp. } & \text { IP } \\ \text { Riboflavin } & \text { Yellow } & \text { Ashbya gossypi } & \text { IP } \\ \text { Rubropanctatin } & \text { Orange } & \text { Monascus sp. } & \text { IP } \\ \beta \text { Carotene } & \text { Yellow-orange } & \text { Blakeslea trisporia } & \text { IP } \\ \text { Astaxanthin } & \text { Pink-red } & \text { Agrobacterium aurantiacum } & \text { RP } \\ \text { Astaxanthin } & \text { Pink-red } & \text { Paracoccus carotinifaciens } & \text { RP } \\ \text { Cathaxanthin } & \text { Dark red } & \text { Bradirhizobium sp. } & \text { RP } \\ \text { Lycopene } & \text { Red } & \text { Fusarium sporotrichioides } & \text { RP } \\ \text { Melanin } & \text { Black } & \text { Saccharomyces neoformis } & \text { RP } \\ \text { Napthoquinone } & \text { Deep blood red } & \text { Cardyceps unilateralis } & \text { RP } \\ \text { Zeaxanthin } & \text { Yellow } & \text { Paracoccus zeaxanthinifaciens } & \text { RP } \\ \beta \text { Carotene } & \text { Yellow-orange } & \text { Fusarium sporotrichioides } & \text { RP } \\ \beta \text { Carotene } & \text { Yellow-orange } & \text { Neurospora crassa } & \text { RP } \\ \beta \text { Carotene } & \text { Yellow-orange } & \text { Phycomyces blaksleeanus } & \text { RP } \\ \text { Unknown } & \text { Red } & \text { Paecilomyces sinclairii } & \text { RP } \\ \text { Astaxanthin } & \text { Pink-red } & \text { Xanthophyllomyces dendrohous } & \text { DS } \\ \text { Lycopene } & \text { Red } & \text { Blakeslea trisporia } & \text { DS } \\ \text { Rubrolone } & \text { Red } & \text { Streptomyces echinoruber } & \text { DS } \\ \text { Torularhodin } & \text { Orange-red } & \text { Rhodotorula sp. } & \text { DS } \\ \text { Zeaxanthin } & \text { Yellow } & \text { Flavobacterium sp. } & \text { DS } \\ \beta \text { Carotene } & \text { Yellow-orange } & \text { Mucor circinelloides } & \text { DS } \\ \text { Unknown } & \text { Red } & \text { Penicillium purpurogenum } & \text { DS }\end{array}$

Note : Industrial Production

Developmental Stage

Research project Phase
(IP),

(DS) and

(RP)

\section{ILow-Cost Substrates}

J. Tinoi, et al., reported that agro-industrial by-products and surpluses that frequently create serious environmental problems may be possibly used as inexpensive carbohydrate sources for microbial fermentations, thus decreasing their initial high biological oxygen demand (BOD) while obtaining biochemical compounds like pigments suitable for pharmaceutical, chemical and food industries ${ }^{34}$. Low cost by products and residues of agro-industrial origin have shown their potential in production of different pigments by diverse group microorganisms. Along this line, variety of substrates and microorganisms has been tested. beta-carotene 
synthesis by citrus products ${ }^{35}$, carotenoids production using whey ultrafiltrate ${ }^{36}$, sauerkraut brine ${ }^{37}$ and peat extract $^{38}$, riboflavin in concentrated rectified grape must ${ }^{39}$, astaxanthin on grape juice ${ }^{40}$ are some promising studies.

These by-products from industrial processes and other agro or domestic sources are pollutants to the environmental and their treatment involves high costs. The conversion of these wastes to value added materials like pigments by microorganisms would provide economic benefits and reduce waste materials impact on environment as pollutants. Many investigations have been performed and are under investigation to diminish the costs and optimize the pigments

production ${ }^{41-48}$. Factors such as carbon and nitrogen source are very important to consider on the selection of wastes as substrates. And pigment production also depends on minerals and other components in some cases. Pigments produced on several wastes were shown in Table 2.

Table 2. Different microorganisms and various inexpensive substrates used for pigments production.

\begin{tabular}{|c|c|c|c|c|}
\hline S.no & Substrate & Microorganism & Pigment type & References \\
\hline 1. & Whey & R. glutinis & $\beta$-carotene & [49] \\
\hline 2. & Potato medium & R. mucilaginosa & $\beta$-carotene & [49] \\
\hline 3. & Crude glycerol & R. glutinis & carotenoids & [50] \\
\hline 4. & Chicken feathers & R. glutinis & carotenoids & [51] \\
\hline 5. & Fermented radish brine & R. glutinis & $\beta$-carotene & [52] \\
\hline \multirow[t]{2}{*}{6.} & Mung bean waste flour and & & & \\
\hline & Sweet potato extract & R. glutinis & carotenoids & [53] \\
\hline 7. & Mustard waste & X. dendrorhous & Astaxanthin & [34] \\
\hline 8. & Plant extracts & $X$. dendrorhous & Astaxanthin & [54] \\
\hline 9. & Coconut milk & $X$. dendrorhous & Astaxanthin & [55] \\
\hline \multirow[t]{2}{*}{10.} & Enzymatic hydrolysates of & & & \\
\hline & prehydrolysed wood & $X$. dendrorhous & Astaxanthin & [56] \\
\hline 11. & Sugarcane waste marine & Streptomyces sp. & melanin & [57] \\
\hline 12. & Jack fruit seed & M. ruber & Monascorubramine & [58] \\
\hline 13. & Rice bran & M. purpureus & Monascorubramine & [59] \\
\hline 14. & Wheat bran & M. purpureus & Monascorubramine & [59] \\
\hline 15. & Sesame oil cake & M. purpureus & Monascorubramine & [59] \\
\hline 16. & Palm kernel cake & M. purpureus & Monascorubramine & [59] \\
\hline 17. & Groundnut Oil cake & M. purpureus & Monascorubramine & [59] \\
\hline 18. & Cassava powder & M. purpureus & Monascorubramine & [59] \\
\hline 19. & Corn cob Substrate & M. purpureus & Monascorubramine & [60] \\
\hline 20. & Grape waste & M. purpureus & Monascorubramine & [61] \\
\hline 21. & Prickly Pear Juice & M. purpureus & Monascorubramine & [62] \\
\hline 22. & Corn steep liquor & M. ruber & Red pigment & [63] \\
\hline \multirow[t]{2}{*}{23.} & Shrimp \& Crab & M. purpureus & & \\
\hline & shell powder & CCRC31499 & Monascorubramine & [64] \\
\hline \multirow[t]{2}{*}{24.} & Hairy roots of madder & & & \\
\hline & (Rubia.tinctorum L.) & P. candidum & Anthroquinone & [65] \\
\hline \multirow[t]{2}{*}{25.} & Marigold flower & & & \\
\hline & (Tagetes.ereecta L.) & R. glutinis & Lutein & [66] \\
\hline 26. & Apple pomace & R. glutinis & carotenoids & [67] \\
\hline 27. & Radish brine & R. glutinis & $\beta$-carotene & [68] \\
\hline 28. & Durian Seed & Monascus.sp & angkak moncolin & [69] \\
\hline 29. & Kinnow waste & M. purpureus МТСС 369 & Bio-pigment & [70] \\
\hline 30. & Sugarcane bagasse & P.echinulatum9A02S1 & Cellulase, Xylanase & [71] \\
\hline 31. & Date syrup & R. glutinis (PTCC 5256) & Carotenoids & [72] \\
\hline \multirow[t]{2}{*}{32.} & Liquid Pineapple & Chromobacterium. & & \\
\hline & & & Violet pigment & [73] \\
\hline 33. & Spoilt Onion & P.purpurogenum & Red Exopigment & [74] \\
\hline
\end{tabular}

\section{Conclusion}

The overall objective of this study is to explore the possibility of pigment production by different microbial isolates from numerous sources on various substrates. Furthermore, the enhanced pigment production capability of carotenoid producing microorganisms in future may lead to the production of nontoxic plant \& microbial food colorants which will be beneficial to the mankind \& livestock. 


\section{References}

[1]. Dziezak, J.D. (1987) Applications of food colorants. Food Technology 41, 78-80.

[2]. Francis, F.J. (1987) Lesser-known food colorants. Food Technology 41, 62-68.

[3]. Francis, F.J. (1989) Food colorants: Anthocyanins. Critical Review in Food Science 28, 273-313.

[4]. Kim, J.K., Park, S.M. and Lee, S.J. (1995) Novel antimutagenic pigment produced by Bacillus licheniformis SSA3. Journal of Microbiology and Biotechnology 5, 48-50.

[5]. Johns, M.R. and Stuart, D.M. (1991) Production of pigment by Monascus purpureus in solid culture. Journal of Industrial Microbiology 8, 23-28.

[6]. Hanagata, N., Ito, A., Fukuju, Y. and Murata, K. (1992) Red pigment formation in cultured cells of Carthamus-Tinctorius L. Bioscience Biotechnology and Biochemistry 56, 44-47.

[7]. Masahiro, K.O., Mine, K., Taya, M., Tone, S. and Ichi, T. (1994) Production and release of anthraquinone pigments by hairy roots of madder (Rubia tinctorum L.) under improved culture conditions. Journal of Fermentation and Bioengineering 77, 103-106.

[8]. Lauro, G.J. (1991) A primer on natural colors. Cereal Foods World 36, 949-953.

[9]. Tibor, C. (2007). Liquid Chromatography of Natural pigments and synthetic dyes. J. Chromatography Library, 71: 11-19.

[10]. Gunasekaran, S., Poorniammal, R., 2008. Optimization of fermentation conditions for red pigment production from Penicillium sp. under submerged cultivation. Afr. J. Biotechnol., 7(12):1894-1898.

[11]. Jiang, Y., Li, H.B., Chen, F., Hyde, K.D., 2005. Production potential of water-soluble Monascus red pigment by a newly isolated Penicillium sp. J. Agric. Technol., 1(1): 113-126.

[12]. Joshi, V.K., Attri, D., Bala, A. and Bhushan, S. (2003). Microbial Pigments. Indian J. Biotech., 2: 362369.

[13]. Blanc, P.J., Loret, M.O., Santerre, A.L., Pareilleux, A., Prome, D., Prome, J.C., Laussac, J.P., Goma, G., 1994. Pigments of Monascus. J. Food Sci., 59(4):862-865. [doi:10. 1111/j.1365-2621.1994.tb08145.x]

[14]. Tseng, Y.Y., Chen, M.T., Lin, C.F., 2000. Growth, pigment production and protease activity of Monascus purpureus as affected by salt, sodium nitrite, polyphosphate and various sugars. J. Appl. Microbiol., 88(1):31-37. [doi: 10.1046/j.1365-2672.2000.00821.x]

[15]. Carvalho, J.C., Pandey, A., Babitha, S., Soccol, C.R., 2003. Production of Monascus biopigments: an overview. Agro Food Ind. Hi-Tech, 14(6):37-42.

[16]. Cho, Y.J., Hwang, H.J., Kim, S.W., Song, C.H., Yun, J.W., 2002. Effect of carbon source and aeration rate on broth rheology and fungal morphology during red pigment production by Paecilomyces sinclairii in a batch bioreactor. J. Biotechnol.,95(1):13-23. [doi:10.1016/S0168-1656(01) 00445-X]

[17]. Engstrom, G.W., Stenkamp, R.E., McDorman, D.J., Jensen, L.H., 1982. Spectral identification, X-ray structure determination, and iron chelating capability of erythroglaucin, a red pigment from Aspergillus ruber. J. Agric. Food Chem., 30(2):304-307. [doi:10.1021/jf00110a022]

[18]. Suhr, K.I., Haasum, I., Streenstrup, L.D., Larsen, T.O., 2002. Factors affecting growth and pigmentation of Penicillium caseifulvum. J. Dairy Sci., 85(11):2786-2794. [doi:10. 3168/jds.S0022-0302(02)74365-8].

[19]. Dufossé, L., 2006. Microbial production of food grade pigments. Food Technol. Biotechnol., 44(3):313321.

[20]. Méndez-Zavala, A., Contreras-Esquivel, J.C., Lara-Victoriano, F., Rodríguez-Herrera, R., Aguilar, C.N., 2007. Fungal production of a red pigment using a xerophilic strain of Penicillium purpurogenum GH2. Rev. Mex. Ing. Quím., 6:267-273.

[21]. Hernández-Rivera, J.S., Méndez-Zavala, A., Pérez-Berúmen, C., Contreras-Esquivel, J.C., RodríguezHerrera, R., Aguilar, C.N., 2008. Culture Conditions to Improve the Red Pigment Production by Penicillium purpurogenum GH2. In: Soto-Cruz, O., Angel, P.M., Gallegos-Infante, A., RodríguezHerrera, R. (Eds.), Advance in Food Science and Food Biotechnology in Developing Countries. Mex Asoc Food Sci Editions, Saltillo, Mexico, p.108-112.

[22]. Mapari, S.A.S., Hansen, M.E., Meyer, A.S., Thrane, U., 2008a. Computerized screening for novel producers of Monascus like food pigments in Penicillium species. J. Agric. Food Chem., 56(21):99819989. [doi:10.1021/jf801817q]

[23]. Mapari, S.A.S., Meyer, A.S., Thrane, U., 2008b. Evaluation of Epicoccum nigrum for growth, morphology and production of natural colorants in liquid media and on solid rice medium. Biotechnol. Lett., 30(12):2183-2190. [doi:10. 1007/s10529-008-9798-y]

[24]. Espinoza-Hernández, T.C., Rodriguez-Herrera, R., Aguilar, Contreras-Esquivel, J.C., 2004. Physiological Characterization of Fungal Strains (Pigment Producers). Proceedings of First Congress of Food Science and Food Biotechnology in Developing Countries. Durango, Dgo, Mexico, p.227-231.

[25]. Aberoumand, A. (2011). A Review Article on Edible Pigments Properties and Sources as Natural Biocolorants in Foodstuff and Food Industry. World J. Dairy Food Sci., 6 (1): 71-78. 
[26]. Ahmad, W.A., Ahmad, W.Y.W., Zakaria Z.A. and Yusof, N.Z. (2012). Application of Bacterial Pigments as Colorant. Springer Briefs in Molecular Science, pp 57-74.

[27]. Santos-Ebinuma VC, Roberto IC, Teixeira MFS, Pessoa Jr A (2013a) Improving of Red Colorants Production by a New Penicillium purpurogenum Strain in Submerged Culture and the Effect of Different Parameters in Their Stability. Biotechnol Prog 29:778-785.

[28]. Santos-Ebinuma VC, Teixeira MFS, Pessoa Jr A (2013b) Submerged culture conditions for the production of alternative natural colorants by a newly isolated Penicillium purpurogenum DPUA 1275. J Microbiol Biotechn 23:802-810.

[29]. N. Nagpal, et al., "Microbial pigments with health benefits-A mini review," Trends in Biosciences, vol. 4, pp. 157-160, 2011.

[30]. C. K. Venil, et al., "Bacterial pigments and their applications," Process Biochemistry, vol. 48, pp. 1065-1079, 2013.

[31]. L. Dufossé, "Microbial Production of Food Grade Pigments," Food Technology \& Biotechnology, vol. 44, 2006.

[32]. C.K.VenilandP.Lakshmanaperumalsamy, "An insightful overview on microbial pigment, prodigiosin," Electronic Journal of Biology, vol. 5, pp. 49-61, 2009.

[33]. W. A. Schroeder and E. Johnson, "Antioxidant role of carotenoids in Phaffia rhodozyma," Journal of general microbiology, vol. 139, pp. 907-912, 1993.

[34]. J. Tinoi, et al., "Utilization of mustard waste isolates for improved production of astaxanthin by Xanthophyllomyces dendrorhous," Journal of Industrial Microbiology and Biotechnology, vol. 33, pp. 309-314, 2006.

[35]. A. Ciegler, et al., "Enhancement of $\beta$-carotene synthesis by citrus products," Applied microbiology, vol. 11, pp. 128-131, 1963.

[36]. G. Frengova, et al., "Formation of carotenoids by Rhodotorula glutinis in whey ultrafiltrate," Biotechnology and bioengineering, vol. 44, pp. 888-894, 1994.

[37]. C. Shih and Y. Hang, "Production of Carotenoids by Rhodotorula rubra from Sauerkraut Brine," LWTFood Science and Technology, vol. 29, pp. 570-572, 1996.

[38]. A. M. Martin, et al., "Growth parameters for the yeast Rhodotorula rubra grown in peat extracts," Journal of fermentation and bioengineering, vol. 76, pp. 321-325, 1993.

[39]. P. Buzzini and J. Rossi, "Semi-continuous and continuous riboflavin production by calcium-alginateimmobilized Candida saitoana 4253 in concentrated rectified grape must.[Erratum: Feb 1999, v. 15 (1), p. 153-159.]," World journal of microbiology \& biotechnology, 1998.

[40]. P. Meyer and J. Du Preez, "Astaxanthin production by a Phaffia rhodozyma mutant on grape juice," World journal of microbiology and biotechnology, vol. 10, pp. 178- 183, 1994.

[41]. M. Vazquez and A. M. Martin, "Optimization of Phaffia rhodozyma continuous culture through response surface methodology," Biotechnology and bioengineering, vol. 57, pp. 314-320, 1998.

[42]. K. Sanjay, et al., "Optimization of carotenoid production by Aspergillus carbonarius in submerged fermentation using a response surface methodology," International Journal of Food Engineering, vol. 3, 2007.

[43]. S. N. Surwase, et al., "Optimization of melanin production by Brevundimonas sp. SGJ using response surface methodology," 3 Biotech, vol. 3, pp. 187-194, 2013.

[44]. P. Park, et al., "Optimization of carotenoid production by Rhodotorula glutinis using statistical experimental design," World journal of microbiology and biotechnology, vol. 21, pp. 429-434, 2005.

[45]. F. Mantzouridou, et al., "Optimization of $\beta$-carotene production from synthetic medium by Blakeslea trispora in a stirred tank reactor and relationship between morphological changes and pigment formation," Food Biotechnology, vol. 16, pp. 167-187, 2002.

[46]. C. Malisorn and W. Suntornsuk, "Optimization of $\beta$-carotene production by Rhodotorula glutinis DM28 in fermented radish brine," Bioresource Technology, vol. 99, pp. 2281-2287, 2008.

[47]. B. D. H. Dung, et al., "Optimization carotenoids production by Rhodotorula glutinis GBDO Uusing design of Plackett-Burman matrix and central composite designresponse surface methodology," in Conference proceedings of Biotechnology for Green Solutions and Sustainable Environment, 2010, p. 25.

[48]. P. Bhosale and R. Gadre, "Optimization of carotenoid production from hyper-producing Rhodotorula glutinis mutant 32 by a factorial approach," Letters in applied microbiology, vol. 33, pp. 12-16, 2001.

[49]. I. Marova, et al., "Use of several waste substrates for carotenoid-rich yeast biomass production," Journal of Environmental Management, vol. 95, pp. S338-S342, 2012.

[50]. C. Saenge, et al., "Potential use of oleaginous red yeast Rhodotorula glutinis for the bioconversion of crude glycerol from biodiesel plant to lipids and carotenoids," Process Biochemistry, vol. 46, pp. 210$218,2011$. 
[51]. M. Taskin, et al., "Use of waste chicken feathers as peptone for production of carotenoids in submerged culture of Rhodotorula glutinis MT-5," European Food Research and Technology, vol. 233, pp. 657-665, 2011.

[52]. C. Malisorn and W. Suntornsuk, "Improved $\beta$-carotene production of Rhodotorula glutinis in fermented radish brine by continuous cultivation," Biochemical Engineering Journal, vol. 43, pp. 27-32, 2009.

[53]. J. Tinoi, et al., "Simplex optimization of carotenoid production by Rhodotorula glutinis using hydrolyzed mung bean waste flour as substrate," Process Biochemistry, vol. 40, pp. 2551-2557, 2005.

[54]. S. Kim, et al., "Increased carotenoid production in Xanthophyllomyces dendrorhous G276 using plant extracts," Journal of Mmicrobiology-Seoul-, vol. 45, p. 128, 2007.

[55]. A. Domínguez-Bocanegra and J. Torres-Muñoz, "Astaxanthin hyperproduction by Phaffia rhodozyma (now Xanthophyllomyces dendrorhous) with raw coconut milk as sole source of energy," Applied Microbiology and Biotechnology, vol. 66, pp. 249- 252, 2004.

[56]. J. Parajó, et al., "Production of carotenoids by Xanthophyllomyces dendrorhous growing on enzymatic hydrolysates of prehydrolysed wood," Food Chemistry, vol. 60, pp. 347-355, 1997.

[57]. V. Vasanthabharathi, et al., "Melanin production from marine Streptomyces," African Journal of Biotechnology, vol. 10, pp. 11224-11234, 2013.

[58]. Babitha, S., Soccol, C. R., and Pandey,

A.: Jackfruit seed-A novel substrate for the production of Monascus pigments through solidstate fermentation, Food Technol. Biotechnol., 44, 465-471 (2006).

[59]. Babitha, S.: Microbial pigments, pp. 147-150, in: Nigam, P.S. and Pandey, A. (Eds.), Biotechnology for agro-industrial residues utilisation, vol. 5. Springer, Heidelberg (2009).

[60]. Velmurugan P, Hur H, Balachandar V, Kamala-Kannan S, Lee KJ, Lee SM, Chae JC, Shea PJ, Oh BT: Monascus pigment production by solid-state fermentation with corn cob substrate. J Biosci Bioeng 2011, 112:590-594.

[61]. SILVEIRA, S. T.; DAROIT, D. J.; BRANDELLI, A. Pigment production by Monascus purpureus in grape waste using factorial design. LWT - Food Science and Technology, v. 41, p. 170-174, 2008.

[62]. HAMDI, M.; BLANC, P. J.; GOMA, G. Effect of aeration conditions on the production of red pigments by Monascus purpureus growth on prickly pear juice. Process Biochemistry, v. 31, n. 6, p. 543-547, 1996. http://dx.doi.org/10.1016/S0032- 592(96)00010-6

[63]. HAMANO, P. S.; KILIKIAN, B. V. Production of red pigments by Monascus ruber in culture media containing corn steep

liquor. Brazilian Journal of Chemical Engineering, v. 23, n. 4, p. 443-449, 2006. http://dx.doi.org/10.1590/S010466322006000400002

[64]. WANG, S. et al. Production of antimicrobial compounds by Monascus purpureus CCRC31499 using shrimp and crab shell powder as a carbon source. Enzyme and Microbial Technology, n. 31, p. 337-344, 2002. http://dx.doi.org/10.1016/S0141-0229(02)00135-7

[65]. Masahiro, K.O., Mine, K., Taya, M., Tone, S. and Ichi, T. (1994) Production and release of anthraquinone pigments by hairy roots of madder (Rubia tinctorum L.) under improved culture conditions. Journal of Fermentation and Bioengineering 77, 103-106.

[66]. Bhosale, P., \& Gadre, R.V., Production of Carotene on tagetes flower by Rhodotorula glutinis. Appl.Microbiol. Biotechnol., 2001, 55:423-427.

[67]. Sandhu D K \& Joshi V K, 1997. Development of apple pomace medium , optimisation of conditions for pigment production by Rhodotorula. Adv Food Res, 19,31.

[68]. Malisorn C, Suntornsuk W: Optimization of beta-carotene production by Rhodotorula glutinis DM28 in fermented radish brine. Bioresource Technol 2008, 99:2281-2287.

[69]. Srianta I, Novita Y, Kusumawati N: Production of monascus pigments on durian seed: effect of supplementation of carbon source. J Pure Appl Microbiol 2012, 6:59-63.

[70]. Panesar R: Bioutilization of kinnow waste for the production of biopigments using submerged fermentation. Int J Food Nutri Sci 2014, 3:9-13.

[71]. M. Camassola and A. J. P. Dillon, "Production of cellulases and hemicellulases by Penicillium echinulatum grown on pretreated sugar cane bagasse and wheat bran in solid-state fermentation," Journal of Applied Microbiology, vol. 103, no. 6, pp. 2196-2204, 2007.

[72]. Moosavi-Nasab Marzieh, Moosavi-Nasab Sahar Sadat, Abedi Elaheh, Askari Hamed 'Carotenoid production by Rhodotorula glutinis in a substrate containing date syrup', The 6th National Biotechnology Congress of Iran 13-15 Aug, 2009, Milad Tower Conference Hall, Tehran-Iran. 
[73]. Claira Arul Aruldass, Rubiyatno, Chidambaram Kulandaisamy Venil and Wan Azlina Ahmad(2015).'Violet pigment production from liquid pineapple waste by Chromobacterium violaceum UTM5 and evaluation of its bioactivity' RSC Adv., 2015, 5, 51524-36.

[74]. S.A. Patil1, Greeshma Sivanandhan and D.B. Thakare(2015) 'Effect of Physical and Chemical Parameters on the Production of Red Exopigment from Penicillium purpurogenum Isolated from Spoilt Onion and Study of its Antimicrobial Activity'Int.J.Curr.Microbiol.App.Sci 4(7): 599-609. 